\title{
All things considered duties to believe
}

\author{
Anthony Robert Booth
}

Received: 19 July 2010 / Accepted: 29 November 2010 / Published online: 14 December 2010

C) The Author(s) 2010. This article is published with open access at Springerlink.com

\begin{abstract}
To be a doxastic deontologist is to claim that there is such a thing as an ethics of belief (or of our doxastic attitudes in general). In other words, that we are subject to certain duties with respect to our doxastic attitudes, the non-compliance with which makes us blameworthy and that we should understand doxastic justification in terms of these duties. In this paper, I argue that these duties are our all things considered duties, and not our epistemic or moral duties, for example. I show how this has the surprising result that, if deontologism is a thesis about doxastic justification, it entails that there is no such thing as epistemic or moral justification for a belief that $p$. I then suggest why this result, though controversial, may have some salutary consequences: primarily that it helps us make some sense of an otherwise puzzling situation regarding doxastic dilemmas.
\end{abstract}

Keywords Epistemology $\cdot$ Ethics of belief · All things considered duties

\section{Introduction}

Doxastic Deontologism can be considered to consist of two claims: firstly, that we are subject to doxastic duties ${ }^{1}$ and, secondly, that doxastic justification should be understood in terms of our compliance with them. But what kind of duties are, according to

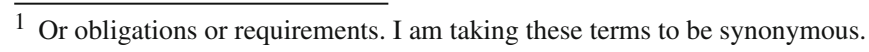

I Would like to thank Conor McHugh, Rik Peels, Herman Philipse, an audience at the 2nd Dutch Annual Practical Philosophy Conference, Groningen, The Netherlands, and an anonymous reviewer at Synthese, for their helpful comments on an earlier draft of this paper.

A. R. Booth (ه)

Department of Philosophy, Utrecht University, Heidelberglaan 6, 3584 CS Utrecht, The Netherlands e-mail: Anthony.Booth@phil.uu.nl; arbooth@fastmail.fm 
the deontologist, the relevant doxastic duties in terms of which we should cash out the justification of belief? For instance, are they moral duties? Are they epistemic duties? Are they prudential duties? I argue that they are our all things considered duties, such that one is justified in believing that $p$ just in case one has not violated an all things considered duty in believing that $p$. Here is the argument:

(1) $\mathrm{S}$ is justified ${ }^{2}$ in believing that $p$ iff $\mathrm{S}$ is blameless in believing that $p$.

(2) $\mathrm{S}$ is blameless in believing that $p$ iff $\mathrm{S}$ has not violated an all things considered duty to believe that $p$.

(3) Therefore, $\mathrm{S}$ is justified in believing that $p$ iff $\mathrm{S}$ has not violated an all things considered duty to believe that $p$.

In the following two sections, I argue for (1) and (2) respectively. In Sect. 3, I discuss (3). The topic of my paper is deontological doxastic justification, but since I won't attempt to defend the possibility that there is such a thing, my thesis is a conditional: if doxastic justification is deontological justification, then doxastic justification involves only our all things considered duties. In Sect. 3, I also examine some potential (and I believe) important implications of (4), primarily that, strictly speaking, there is no such thing as epistemic or moral justification, though there is justification tout court. For those opposed to doxastic deontologism, this implication may be enough to warrant running a modus tollens on my conditional above. That may be an interesting result on its own; however, I end by suggesting that the thesis has some positive further implications: namely, a sort of unity of justification where genuine, ultima facie normative dilemmas over whether one should do one's ethical or epistemic duty with respect to believing that $p$ cannot occur.

\section{$2 \mathrm{~S}$ is deontologically justified in believing that $p$ iff $\mathrm{S}$ is blameless in believing that $p$}

I think this premise hardly requires any argument or explication. According to most deontologists, we are subject to doxastic duties the failure to comply with makes us blameworthy, ${ }^{3}$ so it seems natural to think that, for the deontologist, we are justified when we don't violate such duties (and are thus blameless), and unjustified when we violate them (and are thus blameworthy). One could resist the premise in two ways, however. The first would be to deny that compliance or non-compliance with doxastic duties corresponds to our being blameless or blameworthy, i.e. that one could violate a doxastic duty and nevertheless be blameless (cf. Feldman 2004, Owens 2000). The second would be to argue that the notion of praise is more relevant to deontological justification than is blame, such that the correct premise should be: $\mathrm{S}$ is justified in believing that $p$ iff $\mathrm{S}$ is praiseworthy in believing that $p$ (cf. Weatherson 2008).

The first move seems very dubious when one considers that 'duty' is here being used in a way that is meant to be synonymous with 'obligation' or 'requirement', and it seems particularly infelicitous to say that we are blameless for failing to fulfill

\footnotetext{
2 When I say justification in this paper, I mean deontological justification.

3 For a paradigmatic case in point see Nottelmann (2007).
} 
an obligation (with no excusing condition), or blameworthy for phi-ing even though we were obliged to phi. A different notion of what we normally consider a duty to be must be operative here, in Feldman's case it is some sort of a "role ought". This should be enough to warrant questioning whether deontology is still the thesis we are working with (indeed Feldman 2004 expresses such doubts on pp. 175-176). But the worry becomes even more pressing once we consider that a version of deontologism that relied on that conception of a duty would be consistent with non-deontological accounts (such as Alston's (1989) competing "evaluative" account) of justification. ${ }^{4}$ As such, we are right to wonder what would be left of (or distinctive about) deontologism under such a construal.

An account that has justification cashed out in terms of praise instead of blame is overly demanding unless there are good reasons to prefer it. Unless there are good reasons not to, we should think justification is as easy to attain as possible. If we make the conditions under which we are justified too stringent, we risk skepticism. The conditions are indeed stringent if we think that we are justified just in case we are praiseworthy. Weatherson (2008) thinks there are reasons to bite the bullet here, but as I have argued elsewhere Author and Colleague Booth and Peels (2010) the reasons he offers are inadequate.

\section{$3 \mathrm{~S}$ is blameless for believing that $p$ iff $\mathrm{S}$ has not violated an all things considered duty to believe that $p$}

The argument for (2) is simply this: one cannot be blameworthy for failing to comply with a pro tanto duty, since having a pro tanto duty to $\varphi$ does not rule out the presence of an overriding duty not to $\varphi$. Though it may turn out that there is no overriding duty and thus that we are blameworthy for failing to do whatever the pro tanto duty prescribed, we need to consider whether or not there are such overriding duties if we want to know whether or not to ascribe blame. For example, imagine that I am in the dessert and I see what I take to be an oasis before me. We might say here that I have a pro tanto duty to believe that there is an oasis before me, given the evidence conferred to me by my sight. Am I blameworthy if I don't comply with this duty, however? Surely not, since the duty not to believe (or withhold belief in) the proposition in question has overriding force given that what I see is very likely to be the product of a mirage. In many cases, it may be that not believing what the evidence acquired by my sight prescribes will turn out to be blameworthy, but we can only acknowledge this if we come to realize that in such cases there are no other overriding duties, i.e. I am blameworthy for contravening a doxastic duty just in case that duty turns out to be my doxastic duty all things considered. And since we are blameworthy just in case we fail to comply with our all things considered duties, we are blameless just in case we don't fail to comply with them. One may complain that the bi-conditional in the claim that we are blameworthy just in case we have violated an all things considered duty is too strong. Perhaps there may be some excuse the violator of the all things considered duty

\footnotetext{
4 Alston's evaluative account precisely says that one can make evaluative judgements on belief so long as those judgements do not imply anything about whether the belief is a blameworthy one or not.
} 
can appeal to, such that he or she is not, after all, worthy of blame. One answer would be to attest that to claim that there is a legitimate excuse for violating an all things considered duty is just to claim that the duty was not an all things considered duty, after all. What goes into the "all things considered" description of a duty is precisely considerations that may or may not exculpate belief. However, while this might be a correct treatment of all-things-considered ought, one may consider the notion of a duty to constitutively involve the idea that one can be excused for violating it. If this is the case then we can simply add a rider to the relevant premises as follows:

(1) $\mathrm{S}$ is justified in believing that $p$ iff $\mathrm{S}$ is blameless in believing that $p$.

$(2 *) \mathrm{S}$ is blameless in believing that $p$ iff $\mathrm{S}$ has not *inexcusably* violated an all things considered duty to believe that $p$.

(3*) Therefore, $\mathrm{S}$ is justified in believing that $p$ iff $\mathrm{S}$ has not *inexcusably* violated an all things considered duty to believe that $p .^{5}$

As Richard Feldman has previously mentioned, there is no easy way of arguing against the thesis that there are such overarching all-things-considered duties (or of 'just plain ought' to use Feldman's terminology). However, there is no easy way of arguing for the thesis either, except to say that the fact that we think that people are sometimes blameworthy suggests that there is such a category of just plain ought, since, as I've just argued, we are blameworthy only with respect to our all things considered duties. But, perhaps, a quick reaction to this last claim is to assert that, in cases where, for instance, one believes that there are seven goldfish in the pond (where the evidence clearly indicates there are six) in order to prevent a madman's murder of an innocent child, we can still hold you epistemically blameworthy, if not morally so, for believing that there are seven. But this seems to be a very forced way of putting things. Needless to say, we want to claim that your belief is not epistemically optimal. But can we say you are actually to blame when a duty of another sort has overridden your epistemic duty. Suppose the consequences of actually blaming you are high, and that we want to get our assessment about whether you are blameworthy correct. Saying that you are blameworthy in one sense but not in another does not settle the matter; we need to weigh the relative strengths of doing the epistemically right thing over the morally right thing in this particular situation (i.e. we also weigh the strengths of the different individual duties), that is, we need to know what you should do, all things considered. And it is not as if there is a separate category of epistemic blame as opposed to moral blame; epistemic blame is no different to moral blame: we just have a different standard for assessing blame in each different cases, the blame itself remains unaltered. Or, at least, it seems very hard to imagine what this particular type of blame might be. So it is not as if we are inventing here a new category of all things considered blame, which, of course, requires our considering all things when we seek to attribute it correctly.

5 Thanks to an anonymous reviewer at Synthese for suggesting that I make this modification to the argument. 


\section{$4 \mathrm{~S}$ is justified in believing that $p$ iff $\mathrm{S}$ has not violated an all things considered duty to believe that $p$ : a reductio of deontologism?}

If we accept (3), I think we are forced to say there is no such thing as epistemic (or moral) justification. I think this becomes clearer when one considers the following three principles:

JR: $\mathrm{S}$ is justified in believing that $p$ only if $\mathrm{S}$ has reason to believe that $p$.

JD: $\mathrm{S}$ is justified in believing that $p$ iff $\mathrm{S}$ has not violated an all things considered duty to believe that $p$ [(3) above].

DR: $\mathrm{S}$ has complied by her doxastic duty in believing that $p$ only if $\mathrm{S}$ has reason to believe that $p$.

DR follows (via the transitivity of entailment) from principles JR and JD. If DR and $\mathrm{JD}$ are true, then it follows that an epistemic reason to believe that $p$ only entails there being a pro tanto (or an all things epistemic considered) duty to believe that $p$. If JR, JD and DR are all true, then simply having epistemic 'justification' to believe that $p$ can never entail having all things considered justification to believe that $p$, and since there is only ultima facie tout court or all things considered justification (if justification entails blamelessness), then there is no such thing as epistemic justification. Finally, if moral justification is a type of a deontological justification (in the sense that one is morally justified in $\varphi$-ing iff one has fulfilled one's moral duty with respect to $\varphi$-ing), then, for the same reasons mutatis mutandis, there is no such thing as moral justification.

However, one may now be minded to raise the following question: could an epistemic duty to believe be trumped by another sort of duty, such as a moral duty? I think this is possible. Wouldn't it be in some way irrational for me not to believe that pigs can fly if I have a choice either to believe it or be killed? Or to believe there are six and not seven goldfish in the pond (where the evidence indicates there are seven) if it will bring about the murder of an innocent infant. If these sorts of questions are ever answered in the affirmative, i.e. if it is possible for different sorts of reasons to push and pull us in different directions with respect to our doxastic attitudes, ${ }^{6}$ then what are we to call the duty that does the overriding? So, say we have a pro tanto epistemic duty to believe that $p$ and another pro tanto moral duty not to believe that $p$. Say that the epistemic duty overrides the moral duty and that it is not overridden by any other duty. Does believing that $p$ continue to be an epistemic duty? Likewise, suppose that the moral duty overrides the epistemic; would not believing that $p$ continue to be a moral duty? In other words: what is an all things considered duty to believe, except a

\footnotetext{
6 There are people who think that there can be no non-epistemic reasons for belief (cf. Shah (2006)) though, of course, there are some who think there can (cf. Foley 1993, Jordan 1996). A quick response here would be to claim that since belief can only be up for epistemic scrutiny, there cannot be different sorts of reasons pulling one in differing directions with respect to belief. Thus one can only ever be epistemically blameworthy with respect to belief (and not all-things-considered blameworthy). While I disagree with this claim (cf. Booth 2007), I do not have the space to argue against it in this paper. Once again, my thesis will have to reply on a conditional, namely, if there can be non-epistemic reasons for belief...
} 
duty that has not been trumped by another and one that is commensurable (i.e. can be sensibly weighed against) all other duties? ${ }^{7}$

One might then say that whatever the pro tanto duty's sortal is should carry over when we classify it as a duty that has not been overridden, ${ }^{8}$ viz. an all things considered duty. So if $\mathrm{S}$ has a pro tanto epistemic duty to believe that $p$ and that duty is not overridden, then $\mathrm{S}$ has an all things epistemic considered duty to believe that $p$, and, as such, one can have epistemic justification for a belief that $p$ after all. However, this won't do, since, surely, to say that a duty is an all things epistemic considered duty is simply to deny that it is a duty all things considered (the same goes for all things moral considered). As I have indicated earlier, this is the case even if one particular kind of duty always trumps all other duties; consider (for example) a case where there are two conflicting moral duties of equal strength, but that one of them is 'backed up' or supplemented by an epistemic duty. It could be the case that the presence of the epistemic duty tips the balance in one direction, such that what one of the moral duties prescribes turns out to be one's duty proper. But we could not have worked out that it was had we only considered our moral duties, even if moral duties always override epistemic ones. All things moral considered duties are thus not our all things considered duties, in the case above an epistemic consideration came into play in the determining of what one ought to do all things considered (even if moral duties always trump epistemic duties). So the category of all things considered duty has to be a separate category to moral, epistemic or other kinds of duty and if doxastic justification is about whether or not we violate our all things considered duties, then it too cannot be reduced to mere epistemic justification or mere moral justification, for instance.

As I have mentioned, the thesis that there is no such thing as moral and epistemic justification is very controversial, so controversial, in fact, that one may be inclined to see my argument as a reductio of deontologism. I now try to suggest how this result is not so unappealing. Consider this case I take from Feldman ${ }^{9}$ : A child approaches her parents with a dilemma she is facing as regards a particular action, she knows what the prudent thing to do is, and she knows what the ethical thing to do is. However, she does not know how to decide whether to do the ethical or the prudent thing (and the two are mutually exclusive, let's say). So she asks her parents: "what ought I to do?" It is clear in this case that the child is asking her parents for an answer that will resolve her conflict, in other words, she is asking what she 'plain ought' to do, or what her duty is all things considered. According to Feldman, the child's question is incoherent, since, according to him, there just is no such thing as plain ought. Of course, we feel compelled to help the child out of the dilemma, but we do so by dissolving the dilemma

\footnotetext{
7 We should add that "not being overridden" can only really be a necessary condition for a duty's being an all things considered duty, since, to avoid the ubiquity of such duties, they will need to be of a sufficient normative force or strength. What the appropriate strength might be, as well as how one might measure and determine such a thing as normative 'force', strikes me as an immensely difficult issue, beyond the scope of this paper. One may also wonder what happens when two duties of equal strength conflict. Though I won't argue for it fully here, it seems to me that then we should say that we are all things considered obliged to do a disjunction of the two duties. That would still mean that "not being overridden" is a necessary condition for all things considered duty, though, again, it is probably not sufficient.

8 As I've mentioned, a duty can be 'overridden' by another duty or by relevant excusing conditions.

9 Which he attributes to Stewart Cohen (in conversation).
} 
rather than solving it; we ask whether she has got her moral evaluation completely right, whether her prudential calculation is accurate, or we might try to predict what she might do in similar circumstances. Thus, as Feldman puts it, "there are several meaningful questions that one might ask in the sort of case Cohen envisions. However, as I see it, none of them amounts to the question of what one just plain ought to do" (Feldman 2004, p. 194).

Now, Feldman has not given an argument for the claim that there is no category of all things considered duty, or just plain ought. As he himself admits, "I know of no way to establish that the notion of just plain ought makes no sense" (Feldman 2004, p. 192). Instead, Feldman's strategy is to present a plausible story of what things are like where there is no such thing as all things considered duty. The dilemma the child in the above scenario is facing might well disappear once we ask the questions Feldman envisages, and many such apparent dilemmas may well disappear under appropriate scrutiny. However, there is no reason why (certainly Feldman provides us with no reason why) such dilemmas may sometimes resist that scrutiny. What do we say to the child then? If we admit that belief can be evaluated from a variety of perspectives, then it is possible that we can sometimes be confronted with such dilemmas with regard to belief also. What should I believe: the moral or the epistemic thing? So, here is where the claim that there is no such thing as epistemic and moral justification is advantageous. For if the claim is true, then we can never be faced with an all things considered epistemically justified thing to do versus an all things considered moral thing to do, as I've mentioned this claim just does not make sense. ${ }^{10}$ Of course, this does not rule out there being prima facie dilemmas with respect to doing either our epistemic duty or our moral duty, it just rules out in principle that we can be blameworthy for committing either action or holding either doxastic attitude. So it is not as if there can be an epistemically blameworthy thing to believe, in competition with a morally blameworthy thing to believe; rather, one is only blameworthy with regard to a duty that takes on board all one's pro tanto obligations.

Unfortunately, I do not have an answer as to how exactly one can determine what one's all things considered duty is, but I take it this is a difficult task regardless of whether one thinks there are different kinds of pro tanto doxastic duties. To claim that there is a category of duty all things considered or of just plain ought, is to claim that epistemic-moral dilemmas can be solved. Now, I grant that without an answer as to how exactly one determines what one's all things considered duty is, the claim may be as useful as the claim these dilemmas cannot, in principle, be resolved, though it does offer us a more optimistic picture. Nevertheless, I think we do have more of a reason than mere optimism for thinking such dilemmas can be resolved, since (as I have argued elsewhere Booth 200X) to deny that such dilemmas can be resolved is to deny that the normative question can be resolved (in epistemic terms or otherwise). That is, if we don't have an answer as to why we should believe according to the epistemic optimum versus another option, then we simply don't have an answer as to why we should believe according to the epistemic optimum. The same goes with regard to the question: why be moral? If these are the normative questions in ethics and

10 Though, of course, there can be an all things epistemic considered duty versus an all things moral considered duty. 
epistemology, then denying the solvability of dilemmas is in effect to deny that there is such a thing as epistemic or moral normativity. Again, though it may be optimistic to think that such things epistemic or moral normativity exist, a world where they did not would be an implausibly bleak one.

Nevertheless, the above is not going to convince someone who has independent reason to believe that there are such things as insoluble dilemmas between doing our epistemic and moral duty. And they may be inclined to consider the fact that doxastic deontologism rules them out as yet another strike against deontologism, and hardly as an advantage of holding the view. Yet, the fact that deontologism has these implications gives the thesis some added explanatory scope, and given that there may be many more people inclined to accept the fact that there are no such genuine dilemmas than there are people who accept there is no such thing as epistemic justification, then the implication does lend it some credence that it would not have otherwise.

\section{Conclusion}

The thesis I have proposed in this paper is that if we are going to be deontologists about belief, then we need to be concerned with our all things considered duties pertaining to it. This is because, as I have argued, deontologism about belief needs to be a thesis about blameworthiness, and we are only blameworthy with regard to our all things considered duties. However, I have also argued that there is an interesting upshot to this, namely that there is no such things as epistemic or moral doxastic justification, though there can be doxastic justification tout court. For many, I suspect, these results, if true, will be unpalatable enough to warrant questioning the viability of deontologism altogether. I hope I have done something in the last section to make the results more appealing, primarily by suggesting their resonance with the Kantian ideal of the 'unity of reason'. Perhaps deontologism in contemporary epistemology has been all too divorced from its Kantian connotations, but it should not surprise us too much that when properly construed it will have strong affinities with Kant's project. No bad thing, I believe.

Open Access This article is distributed under the terms of the Creative Commons Attribution License which permits any use, distribution, and reproduction in any medium, provided the original author(s) and the source are credited.

\section{References}

Alston, W. P. (1989). The deontological conception of epistemic justification. In W. P. Alston (Ed.), Epistemic justification: Essays in the theory of knowledge. Ithaca, NY: Cornell University Press.

Booth, A. R. (2007). The two faces of evidentialism. Erkenntnis, 67(3), 401-417.

Booth, A. R. (200X). The sources of epistemic normativity. Unpublished Manuscript.

Booth, A. R., \& Peels, R. (2010). Why responsible belief is blameless belief. The Journal of Philosophy (forthcoming).

Feldman, R. (2004). The ethics of belief. In E. Conee \& R. Feldman (Eds.), Evidentialism: Essays in epistemology. Oxford, UK: Oxford University Press.

Foley, R. (1993). Working without a net: A study in egocentric epistemology. Oxford, UK: Oxford University Press. 
Jordan, J. (1996). Pragmatic arguments and belief. American Philosophical Quarterly, 33(4), 409-420. Nottelmann, N. (2007). Blameworthy belief: A study in epistemic deontologism. Dordrecht: Springer. Owens, D. (2000). Reason without Freedom: The problem of epistemic normativity. London: Routledge. Shah, N. (2006). A new argument for evidentialism. The Philosophical Quarterly, 56, 481-498.

Weatherson, B. (2008). Deontology and descartes' demon. The Journal of Philosophy, 105, 540-569. 